\title{
The Empty Demand for Solidarity
}

\author{
Lisa Dillinger (University of Zurich)
}

\begin{abstract}
:
In times of crisis, an increasing number of voices are being raised calling for solidarity. It can therefore be assumed that the ability to behave in solidarity is of public interest and should be cultivated. Can and must solidarity then be an educational goal and in what way could it be implemented? A first step in answering these questions is to determine the content of the concept of solidarity, which has been interpreted in many different ways. In this article, I follow Simon Derpmann's understanding of solidarity in order to propose a pedagogical view based on it. Consequently, two educational goals can be named that are conducive to the cultivation of solidarity: First, moral identity as the assurance and commitment to one's own moral convictions, and second, the ability to collaborate in order to pursue shared and common goals with others. Finally, there remains the question of whether solidarity has an intrinsic value for the education of subjects, or whether it is a political endeavor that has no educational ethical justification in pedagogical debates.
\end{abstract}

Keywords:

civic education; collaborative learning; moral education; moral identity; solidarity

In his novel "The Age of the Fish," first published in 1937, Ödön von Horváth describes how the students in a school class ally against their teacher and try to have him replaced. The trigger for this resistance by the students was a reprimand from the teacher that seemed unjust and unacceptable to them. Thus, Horváth provides a literary example of what we generally understand by solidarity; a group banding together in the face of an experienced subjective injustice to take action against it. However, and there we see the morally inflated normative taint that often attaches to the notion of solidarity, the teacher's rebuke referred to the fact that one of the students had made inhumane remarks toward Black people. Quite intuitively, the students' behavior may rightly seem less valuable or praiseworthy to us in light of this information, and accordingly, we would possibly describe this scene less in terms of solidarity. Why do we resist describing the situation Horváth reports as one of solidarity? It seems plausible to be in solidarity with one's classmates; after all, one feels connected to them because of the shared experience. The way they behave - they jointly write a letter to the principal seems an appropriate means to pursue their end, so it is plausible to speak of successful solidary practice. If solidarity were an educational goal at the school Horváth imagines, it would have been fulfilled and the situation could be understood as a success. Nevertheless, there seems to be an implicit understanding of solidarity that cannot be reconciled with this situation. This article attempts to explicate these implicit assumptions and thereby, on the one hand, provide a foundation for pedagogical discussions of solidarity and, at the same time, show why the common use of solidarity, as it occurs in public discourse, is misleading and lacks content.

In the following, therefore, a clarification of the concept will first be carried out, which does not so much aim at a generally valid notion of solidarity, but rather creates a basis for a fruitful treatment of the demands for solidarity, especially in the pedagogical context. In this framework, two educational goals that are prerequisites for solidarity will be focused on, namely moral identity and the ability to collaborate. Finally, the resulting ethical challenges are discussed.

\section{Concepts and Misunderstandings of Solidarity}

The theoretical treatment of solidarity in the Western world, as we know it today, goes back to the sociology of Emile Durkheim (2013) and in particular to his work "The Division of Labor in Society", in which at the end of the $19^{\text {th }}$ century he seeks an answer to the question of what unites people in industrialized times. For Durkheim, solidarity is thus a descriptive concept that explains how the functional differentiation of society creates new dependencies, which are the basis of modern society. It is only with the social philosophical discussion of solidarity that a normative understanding has developed. Habermas, for example, names it as the "flipside of justice" (Habermas, 1991, p. 100). While justice serves to protect the individual, solidarity is supposed to ensure the protection of the lifeworld, which is a 
prerequisite for individualism in the first place. Brunkhorst, following Habermas, describes solidarity as a "form of moral thinking that integrates in the lifeworld and system" (Brunkhorst, 2002, p. 15). In this tradition, solidarity corresponds to the moral and altruistic inclination of human beings and represents a contrast to purely purposeful thinking and acting. Today, solidarity is accordingly used synonymously with a commitment against injustice of any kind or a responsibility towards others (see e.g., Young, 2006; Held et.al., 2011; Arango, 2012; ter Meulen, 2016). Vogt therefore also speaks of a "moral grammar of solidarity" (Vogt, 2014, p. 95) and Wiggins goes so far as to regard solidarity as the "root of the ethical" (Wiggins, 2009, p. 239).

When solidarity is publicly demanded in times of social crises, there is rarely a determination of the content of this demand. While on the one hand a basic competence for solidarity is assumed or presumed, on the other hand a certain understanding of solidarity is equally implied. However, some of the assumptions that underlie calls for or discussions of solidarity are built on misconceptions, so they lack significance. In the following, Derpmann's concept of solidarity (Derpmann, 2013) will be introduced by clarifying two such misunderstandings, which should eventually allow for a constructive pedagogical discussion on the topic of solidarity.

The first misunderstanding concerns the normative interpretation of solidarity as something fundamentally 'good'. This can be seen in the fact that the demand for solidarity - for example as a declared goal in mission statements or the like - is often stated completely without any definition of its content. Solidarity points beyond one's own individual interest and allows people to collaborate with each other in the face of crises or injustices without inevitably being affected or equally affected. This moment of decentration from one's own egocentric standpoint is certainly important for human development, but it is not necessarily morally desirable. As we have seen in Horváth's introductory example - and in different historical events solidarity understood in this way can also be present in individuals who ally themselves on the basis of a reprehensible cause. If one wants to interpret and understand solidarity morally, it is crucial to look at the reasons for it.

What is important and normatively significant is therefore not the question of whether solidarity exists, but on what basis this solidarity exists. Simon Derpmann refers to this in his contribution in this issue as the 'solidum' of solidarity. He points out that not every situation that appears to be solidary can be morally justified (Derpmann, 2013, p. 201). Consequently, if we want to maintain solidarity as a normative reference, we need to be able to agree on legitimate and illegitimate reasons for solidarity. This involves understanding solidarity as a connection that individuals make on the basis of shared moral identifications
(Derpmann, 2013, p. 27). Moral identifications are value judgements that have an action-guiding and identity-forming effect on the individual (Derpmann 2013, p. 37). In solidarity, such identifications, when shared with others, become their common cause. This gives both the identification and the relationship to those who share it a new significance (Derpmann, 2013). Understanding, then, that solidarity is not moral by itself, but is built on shared identifications that can be morally judged, suggests the relevance of determining the content of different solidarities. If the underlying identifications are ethically contestable or exclusionary, a substantive critique can be produced that is not possible in the case of indeterminate demands for solidarity and its interpretation as generally 'good'.

The dismissal of partial solidarity in principle represents the second misunderstanding concerning solidarity. Through the moral turn in the use of the concept of solidarity, the standard of moral universalism is applied to it. Solidarity, according to the common misconception, must be given to all people, otherwise it is biased and therefore to be rejected. Combined with obliviousness to the reasons for solidarity, this leads to an interpretation of partiality as a special relationship between persons based in singular affiliations. For example, as in Horváth's story, students are assumed to be in solidarity because of their shared roles in school. While such roles speak to a particular relationship with one another, they are not sufficient to explain solidary connections and commitments that often extend beyond the shared experience. This circumstance is taken into account in different ways in theory. In part, a fundamental solidarity with others based on recognized shared humanity is assumed (Wiggins, 2009). Rorty makes suffering as part of the human condition the unifying feature of solidarity (Rorty, 1989), while Habermas speaks of solidarity if it includes "all subjects capable of speech and action" (Habermas, 1988, p. 328 ) in the communication society. In one way or another, they describe an essential characteristic of human beings that grounds solidarity and is thus in principle universal. In this understanding, solidarity as a desirable moral activity would also be measured by the fact that it is felt universally with all (see, e.g., Brunkhorst, 2002).

The criticism leveled against a partialist understanding of solidarity refers primarily to the idea that such preference must always be accompanied by exclusion, and that solidarity is then sometimes limited to arbitrary affiliations. This accusation is to be countered with a reminder of the above section on the reasons for solidarity. The moral significance of solidarity is measured by its underlying identifications. If these identifications are singular features that a person has not voluntarily acquired, their moral significance can also be doubted. On the other hand, there may be a desirable underlying moral identification that is conceivable universally as a principle, but the group of those who share this principle is nevertheless a particular circle of people (Derpmann, 2013, p. 85). 


\section{Educating for Solidarity?}

If we understand solidarity with Derpmann, as a voluntary special commitment to others who share the same moral identification, certain goals can be named that can be pursued pedagogically to enable children to act in solidarity. The first goal concerns the ability to deal with ethical and moral issues, to recognize their relevance, to develop a point of view that can then guide one's actions, and finally to articulate and come to an understanding about these moral identifications. In this context, we speak of moral identity (Hardy \& Carlo, 2011). In order for moral judgements to inform action, they must become an identity-forming variable in the self-image of individuals. Thus, not only is the competence to weigh moral issues required, but morality must be given such a central place in one's identity that it becomes an obligation. Moral identity then also represents a model for explaining the congruence between moral judgement and moral action.

Research on moral identity is currently limited mainly to moral psychology but integrates well with considerations of moral education. What is intriguing about this model is that it builds on and points beyond the question of moral judgement and its development to clarify how moral judgements become action-guiding and how they are weighed against other judgements, such as convention, personal advantage, or taste (Hardy \& Carlo, 2011). Moral education for moral identity is not to be understood as something that makes people 'good' in the sense of conforming to super-personal and externally defined moral principles, but rather as helping to clarify and articulate one's own moral intuitions beyond that in order to be able to integrate them into one's identity (Herzog, 1991).

A second goal of education, if solidarity is to remain desirable, is the ability to collaborate. Collaboration differs from cooperation in that the former involves working together toward a shared goal, whereas the latter involves members of a group pursuing their individual goals. In pedagogical theories much attention is given to cooperative learning (e.g Slavin, 1983), group projects and cooperative working and learning mainly serve one's own learning process which is understood as independent and individual. This model of course has its justifications but should be neglected for the present topic of solidarity. Solidarity does not describe the pursuit of one's own interests, but the collaborative activity to achieve a common goal (Jaeggi, 2001, p. 293). An exemplary way to strengthen collaborative skills is to teach "specific dialogic strategies for thinking collectively" (Rojas-Drummond et al., 2008, p. 179) in order to exchange ideas and positions and to develop a common cause.
The Art of not Anticipating - Solidarity as an Intrinsic Value

Now, moral identity and collaborative abilities could also be taught and justified without attributing them to the ability for solidarity. Theories of moral education are as old as education itself, and the ability to collaborate could also be defended in terms of the demands that modern societies make on their workforce and citizens. At the same time, the demand for solidarity appears to spring from a political logic that uses it to pursue specific social goals that are rarely communicated transparently. As a result, a pedagogical demand for solidarity would have to face a whole series of accusations that recognize behind it, at best, paternalistic coercion and, at worst, ideological indoctrination. Under these circumstances, is there a need for a pedagogical discussion of solidarity, and is it at all legitimate to declare solidarity an educational goal? These questions can be answered in two ways.

On the one hand, solidarity can be named as a goal in the context of political or civic education. However, it should then be noted that there is an extrinsic interest in this education, i.e., that a political objective is being pursued. For example, in the context of critical race theories, solidarity is set as a goal of education without defining it in terms of content, other than it should be felt with both close and different others alike (e.g. Mecheril, 2018). Implicitly however, it is quite obvious what specific kind of solidarity is meant and to whom it should or should not be extended (Mecheril, 2018). This kind of pedagogical discussion does not seem to do justice to the idea that children and future citizens should be enabled to independently discuss the type of society in which they want to live. Moral questions and principles can and should be addressed with them, but they must not be anticipated. In other words, education can only help to cultivate the ability of solidarity but should not prescribe on what grounds or whether solidarity is then actually practiced. Only then is it ethically justifiable without imposing one's own values on a coming generation.

On the other hand, an argument can be made for the intrinsic value of solidarity for the individual. A purely external, political interest in teaching new generations the ability to show solidarity would be a weak reason to deal with solidarity in educational terms. The argument that the capacity for solidarity can empower individuals in a society seems more compelling. The structures and institutions of society can appear overpowering without individuals being able to bring about change (see Young, 2006). In contrast, the awareness of already being in dependencies and relations qua existence and then connecting with each other on the basis of these dependencies and relations expands the agency of individuals by enabling them to pursue common goals. The ability to engage in dialogue with others on the basis of moral identifications and convictions not only legitimizes common demands (Jaeggi, 2001, p. 292), but also opens up the 
possibility to reflect on and differentiate one's own convictions, to come closer to one's own self-image through collaborative actions. Solidarity is then not only an active expression of one's own indignation, but also the ability to act in resistance.

\section{Conclusion}

Demands for solidarity, such as those made at the time of a pandemic, indicate a public interest in solidarity. Often, however, such demands are poorly defined in terms of content and this can be problematic for a concept such as solidarity, which is attributed many interpretations and aspects of meaning. For this reason, Derpmann's (2013) understanding of solidarity was presented in this article, directed at two misunderstandings: that solidarity can be evaluated regardless of the underlying convictions that inspire solidarity and that solidarity should not be partial. Instead, it was argued that it is the reasons for and means of solidarity that must face moral scrutiny. If solidarity is to be a moral demand, the underlying principle must be universally valid, but solidarity itself must not. It is limited to those who share those principles. It is precisely the partiality expressed in the term that distinguishes solidarity from pure humanism: people who are in solidarity with each other are committed beyond the generally required morality, without this partiality arising from a special affective relationship.

If one agrees with this understanding of solidarity and wants to discuss it in terms of education, the question arises with which abilities people are to be equipped so that they are able to practice solidarity. It has been suggested that two essential foundations lie in moral identity and the ability to collaborate. Moral identity describes the degree of relevance that morality assumes on one's self-image, so that moral reasons, among other reasons, become action-guiding. The ability to collaborate enables individuals to agree with others on common goals and to pursue them. Assuming that the subjective principles are different, the ability to establish a common consent also plays an important role.

Finally, an attempt was made to find answers to the question of if and why solidarity should be dealt with from the point of view of educational theory, or whether it in fact originates from a political logic and therefore if it would be an illegitimate influence to educate students for solidarity. This fear can be countered in two ways. First, solidarity is an important political and social skill that can be cultivated without concern as long as the moral principles on which it is based are not preempted. To this end, it is important that solidarity is not morally exaggerated and that the interests that exist in the capacity for solidarity are made transparent. A key difference between political and pedagogical demands for solidarity, therefore, is that the former must not be empty, but must state the grounds of solidarity demanded in order to be morally significant. Pedagogical demands for solidarity, on the other hand, must remain empty - or open - for ethical reasons to encourage the ability for solidarity without anticipating its reasons. On the other hand, an argument was made for the intrinsic value of solidarity by understanding individuals as relational beings who, as a result of modern society, live in structures that are contingent and often unjust. In order not to be powerless in the face of these structures, it can be essential to communicate, ally, and become active with others on the basis of shared moral convictions. Solidarity is thus also to be seen as an empowerment that helps the individual not only to submit to the given, but to question it. Solidarity can then be a tool for appropriating the world and collaborating on a society in which one wants to live.

\section{References}

Arango, R. (2012). Solidarität und soziale Demokratie. Law and Politics in Africa, Asia and Latin America, 45(4), $385-393$. https://doi.org/10.5771/0506-7286-2012-4-385

Brunkhorst, H. (2002). Solidarität. Von der Bürgerfreundschaft zur globalen Rechtsgenossenschaft. Suhrkamp.

Derpmann, S. (2013). Gründe der Solidarität. Mentis.

Derpmann, S. (2019). Solidarität. In C. Hiebaum (Ed.), Handbuch Gemeinwohl (1-13). Springer VS.

Durkheim, É., Halls, W., \& Lukes, S. (2014). The division of labor in society. Free Press.

Habermas, J. (1988). Moralität und Sittlichkeit: Treffen Hegels Einwände gegen Kant auch auf die Diskursethik zu? Revue Internationale de Philosophie, 42(166), 320-340.

Habermas, J. (1991). Erläuterungen zur Diskursethik. Suhrkamp.

Hardy, S., \& Carlo, G. (2011). Moral Identity: What is it, how does it develop, and is it linked to moral action? Child Development Perspectives, 5(3), 212-218. https://doi.org/10.1111/j.1750-8606.2011.00189.x

Held, J., Bibouche, S., Billmann, L., Holbein, M., Kempf, M., \& Kröll, T. (2011). Was bewegt junge Menschen? Springer VS. 
Herzog, W. (1991). Die Banalität des Guten. Zur Begründung der moralischen Erziehung. Zeitschrift für Pädagogik, 37(1), 41-64.

Horváth, Ö.v. (1978). The Age of the Fish. Penguin modern classics.

Jaeggi, R. (2001). Solidarity and Indifference. In R. ter Meulen, W. Arts, W., \& R. Muffels (Eds.), Solidarity in health and social care in Europe (287-308). Springer Science+Business Media.

Jaeggi, R. (2016). Entfremdung. Zur Aktualität eines sozialphilosophischen Problems. Suhrkamp.

ter Meulen, R. (2016). Solidarity, justice, and recognition of the other. Theoretical Medicine and Bioethics, 37(6), 517-529. https://doi.org/10.1007/s11017-016-9387-3

Mecheril, P. (2018). Solidarität als Anspruch rassismuskritischer politischer Bildungsarbeit. Überblick. Zeitschrift der Informations- und Dokumentationsstelle gegen Gewalt, Rechtsextremismus und Ausländerfeindlichkeit in Nordrhein-Westfalen, 2/2018, 3-7.

Rojas-Drommond, S.M., Alberrán, C.D., \& Littleton, K.S. (2008). Collaboration, creativity and the co-construction of oral and written texts. Thinking Skills and Creativity, 3(3), 177-191. https://doi.org/10.1016/j.tsc.2008.09.008

Rorty, R. (1989). Contingency, Irony, and Solidarity. Cambridge University Press.

Slavin, R.E. (1983). Cooperative Learning. Longman.

Vogt, M. (2014). Zur moralischen Grammatik der Solidarität und ihrer (begrenzten) Anwendbarkeit auf intergenerationale Konflikte. Annual Review of Law and Ethics, 22, 95-114.

Wiggins, D. (2009). Solidarity and the root of the ethical. Tijdschrift voor Filosofie, 71(2), 239-269. https://doi.org/10.2143/TVF.71.2.2038077

Young, I. (2006). Responsibility for justice. Oxford University Press.

\section{Recommended Citation}

Dillinger, L. (2021). The empty demand for solidarity. On Education. Journal for Research and Debate, 4(10). https://doi.org/10.17899/on_ed.2021.10.5

About the Author

Lisa Dillinger, MA, is a $\mathrm{PhD}$ candidate and research and teaching assistant at the Institute of Education, University of Zurich. Her research interests include moral education, educational ethics as well as educational inequality. 